\author{
Anna Ziębińska-Witek \\ (Uniwersytet Marii Curie-Skłodowskiej w Lublinie) \\ https://orcid.org/0000-0003-2682-748X
}

\title{
Muzealizacja komunizmu w Polsce i w Europie Zachodniej*
}

\author{
Musealization of Communism in Poland and in Western Europe
}

\section{STRESZCZENIE}

W artykule wyodrębniono i poddano analizie trzy występujące w Polsce modele ekspozycji o komunizmie. Na konkretnych przykładach, takich jak: Europejskie Centrum Solidarności i Muzeum Powstania Poznańskiego - Czerwiec 1956 (model tożsamościowy), izby pamięci ofiar komunizmu i Muzeum ks. Jerzego Popiełuszki (model martyrologiczny) oraz Muzeum PRL i Czar PRL (model nostalgiczny) autorka zanalizowała odmienne cele i strategie wystawiennicze ekspozycji, dekonstruując ich narracje. Polskie wystawy zestawiała z fragmentem ekspozycji historycznej w Domu Historii Europejskiej w Brukseli, co pozwala zaakcentować różnice w postrzeganiu komunizmu w Polsce i w Europie Zachodniej.

Słowa kluczowe: muzeum, reprezentacja, komunizm, instytucjonalizacja historii, ekspozycja

W ostatnich latach doświadczamy zjawiska zwanego memory boom, a wraz z nim obsesyjnego wręcz zainteresowania zagadnieniem pamięci i - co za tym idzie - nadprodukcji artykułów naukowych na ten temat. Nie jest moim zadaniem przytaczanie wszystkich tytułów i autorów zajmujących się tą problematyką. W niniejszym tekście odwołam się jedynie do tych pojęć, które uznaję za niezbędne dla poruszanego tematu.

Podstawową i nadrzędną kategorią w interesującej mnie problematyce jest pamięć kulturowa, której nie należy utożsamiać z pamięcią zbiorowa,

* Publikacja powstała w wyniku realizacji projektu badawczego, nr 2014/13/B/ HS3/04886, finansowanego ze środków Narodowego Centrum Nauki. Tekst zawiera fragmenty monografii Muzealizacja komunizmu w Polsce i Europie Środkowo-Wschodniej, Wydawnictwo UMCS, Lublin 2018. 
zagęszczającą treści, intensyfikującą symbole i odwołującą się do silnych emocji. Pamięć kulturowa „służy przekazywaniu doświadczeń i wiedzy ponad granicami pokoleń, wytwarzając w ten sposób społeczną pamięć długoterminową" ${ }^{\prime 1}$, przy czym opiera się na zewnętrznych mediach $i$ instytucjach, które przekazują informacje. Pomaga społeczeństwu w komunikacji w długofalowej perspektywie historycznej i stabilizuje tożsamość opartą na tradycji i szeroko zakrojonych doświadczeniach historycznych. Przekazany na nośniki materialne (artefakty, teksty) repertuar pamięci kulturowej wymaga ciągłego dopasowywania i odnawiania, a także odczytywania i dyskusji, gdyż jest wciąż dostosowywany do potrzeb i wymogów teraźniejszości².

W obrębie podstawowej struktury pamięci kulturowej funkcjonuje pamięć funkcjonalna i magazynująca. Ta pierwsza zachowuje przeszłość jako teraźniejszość w formie kanonu, ta druga magazynuje i ocala minioną przeszłość w formie archiwum ${ }^{3}$. Owa problematyka jest złożona, ale ponieważ zakres niniejszego tekstu jest ograniczony, skoncentruję się na pytaniu o udział muzeów historycznych w konstruowaniu kanonu pamięci o komunizmie.

Zgodnie z definicją Andrzeja Szpocińskiego:

[...] kanon [...] to zbiór należących do przeszłości osób, wydarzeń, zjawisk i wzorów, których znajomość jest najbardziej powszechna i uznawana za część obowiązkowej wiedzy wspólnej. Składa się na niego zasób tych informacji, które znać powinna każda osoba funkcjonująca jako pełnoprawny członek społeczności. Kanon pamięci odnoszony jest do określonej zbiorowości, a jego elementy symbolizują grupę, a także idee, wartości i wzory zachowań uznawane przez jej członków za szczególnie ważne ${ }^{4}$.

Włączenie do kanonu to proces obejmujący selekcję, wartość i trwanie. Jak pisze Aleida Assmann, „selekcja zakłada podejmowanie decyzji i konflikty władzy; przypisanie wartości nadaje obiektom aurę i czcigodność; głównym celem jest zaś trwanie w pamięci kulturowej". Kolejne pokolenia nie muszą kanonu od nowa ustanawiać, trwa on dłużej niż całe gene-

1 A. Assmann, Między historią a pamięcią. Antologia, red. M. Saryusz-Wolska, Warszawa 2013, s. 55. „Pamięć kulturowa - pisze Aleida Assmann - dzięki wbudowanej w jej strukturę relacji napięć między pamiętaniem i zapomnieniem, świadomym i nieświadomym, widocznym i utajonym, jest nieporównanie bardziej złożona i zdolna do przemian (ale też bardziej krucha i problematyczna) niż pamięć zbiorowa, nastawiona na jednolitość i jednoznaczność". Zob. ibidem, s. 57.

2 Ibidem, s. 56.

3 Ibidem, s. 76.

4 A. Szpociński, Przemiany obrazu przeszłości Polski: analiza słuchowisk historycznych dla szkót podstawowych 1951-1984, Warszawa 1989, s. 21-22. 
racje, jest reinterpretowany zgodnie $\mathrm{z}$ duchem $\mathrm{czasu}^{5}$. Kanon pełni rolę pamięci aktywnej, która definiuje i wspiera tożsamość kulturową, jest bardzo selektywny i zbudowany na zasadzie wykluczenia. Archiwum z kolei przechowuje to, o czym się zapomina .

Muzea historyczne należą do jednych z najważniejszych instytucji publicznych, które zajmują się edukacją historyczną. Są zatem niezwykle skutecznym narzędziem tworzenia kanonu pamięci. Jako źródła wiedzy o przeszłości plasują się na drugim (po dyskursie akademickim) miejscu wraz z filmem i literaturą piękną?

Obecnie polski kanon pamięci o komunizmie wciąż się kształtuje i zmienia, a Polska to jedno z niewielu państw byłego bloku sowieckiego, które nie posiada muzeum poświęconego całemu okresowi komunizmu (najbliższe temu jest niedawno otwarte Europejskie Centrum Solidarności). Wynika to z wielu czynników. Jadwiga Staniszkis twierdzi, że polskie społeczeństwo zapomina lub/i wypiera ze świadomości ten okres w swojej historii. Badaczka stawia trzy hipotezy wyjaśniające ów stan. Pierwszą przyczyną jest, jak zakłada, „nieczyste sumienie” (szczególnie środowisk inteligenckich) ${ }^{8}$. „Większość społeczeństwa - pisze J. Staniszkis - nie chciała pamiętać spustoszeń w psychice, jakie pozostawiła «mała stabilizacja», czy - charakterystyczne dla tamtego okresu «realistyczne» myślenie, lokujące legitymizację komunizmu nie w jego zaletach [...], ale - jak się wydawało - w jego historycznym braku alternatywy" ${ }^{\prime \prime}$. Druga hipoteza zakłada, że doświadczenie Solidarności, które ówcześnie było wyrażane głównie w kategoriach moralnych, obecnie, gdy zniknął mit racji moralnej, nie znajduje innego języka dla wyrażenia tamtych wydarzeń, przeżyć, emocji i poczucia wspólnoty ${ }^{10}$. Po trzecie, mamy do czynienia z brakiem międzypokoleniowego przekazu, co „łączy się z faktem, iż dla wielu nowe informacje (między innymi o stopniu penetracji ich środowisk przez służby specjalne w czasach komunizmu) dewaluują - bo pokazują jako złudzenie - ich własny obraz komunizmu, czy jego strzępy, jakie nosili w pamięci"11.

Nie podważając powyższych hipotez, warto zauważyć, że zapominanie o przeszłości jest naturalnym elementem tworzenia się kanonu pa-

5 A. Assmann, Między historia, s. 78.

6 Ibidem, s. 86.

7 A. Szpociński, II wojna światowa w komunikacji społecznej, w: Między codziennościa a wiel$k a$ historią. Druga wojna światowa w pamięci zbiorowej społeczeństwa polskiego, red. P.T. Kwiatkowski, L.M. Nijakowski, B. Szacka, A. Szpociński, Gdańsk-Warszawa 2010, s. 66-67.

8 J. Staniszkis, Antropologia władzy. Między Traktatem Lizbońskim a kryzysem, Warszawa 2009, s. 183.

9 Ibidem, s. 186.

10 Ibidem, s. 188-189.

11 Ibidem, s. 194-195. 
mięci. W praktyce to pamiętanie jest aktywnością wyjątkową i wymaga specjalnych narzędzi ${ }^{12}$. Zapominanie jest konstytutywne dla formowania nowej (postkomunistycznej) tożsamości społeczeństwa: pozbywamy się wspomnień, które nie służą naszym obecnym celom i „bieżącej” tożsamości. Zapamiętujemy rzeczy istotne z nowej perspektywy społeczno-kulturowej ${ }^{13}$.

Nie oznacza to jednak, że nie istnieją żadne reprezentacje poświęcone najbliższej przeszłości. Wręcz przeciwnie, powstają wystawy i muzea (zarówno państwowe, jak i prywatne), które przedstawiają pojedyncze wydarzenia lub poszczególne procesy historyczne mieszczące się w ogólnych ramach okresu 1944-1989. Prezentują one odmienne podejścia do tematu oraz różne strategie wystawiennicze. Na użytek niniejszego artykułu wyodrębnię trzy podstawowe typy muzeów/wystaw reprezentujące polski system komunistyczny.

Typ pierwszy i z perspektywy kanonu pamięci najważniejszy, gdyż odzwierciedla oficjalną politykę historyczną państwa polskiego, to tzw. muzea tożsamościowe (określenie Roberta Traby) lub heroiczne. Przykładami takich ekspozycji są Europejskie Centrum Solidarności w Gdańsku oraz Muzeum Powstania Poznańskiego - Czerwiec 1956 roku w Poznaniu (oddział Wielkopolskiego Muzeum Niepodległości).

Te miejsca są odpowiedzią na problemy z językiem zdiagnozowane przez J. Staniszkis:

Wróciło milczenie, dezartykulacja (z jednym słowem-kluczem „powrót do normalności") i znów - strach przed śmiesznością używania wielkich słów w zderzeniu z codziennym, indywidualnym zabieganiem. Kres solidarnościowej utopii oznaczał bowiem kres wiary, że możliwe są zbiorowe, odnoszące się do całej wspólnoty rozwiązania. Powrócono do pamiętanych z epoki Gierka, indywidualnych strategii przetrwania i awansu ${ }^{14}$.

Oba wymienione powyżej muzea są miejscami, które w swoich reprezentacjach przeszłości posługują się głównie kategoriami moralnymi, mniej politycznymi, a prawie $\mathrm{w}$ ogóle materialnymi, próbują wyrazić zbiorowe doświadczenie i przywrócić utracone (poprzez transformację i proces indywidualizacji) poczucie wspólnoty narodowej.

Na stronie internetowej Muzeum Czerwca 1956 możemy przeczytać:

12 Zob. A. Assman, From "Canon and Archive", w: The Collective Memory Reader, red. J.K. Olick, V. Vinitzky-Seroussi, D. Levy, Oxford 2011, s. 334-337.

13 Zob. P. Connerton, Seven Types of Forgetting, "Memory Studies” 2008, 1, s. 59-71, http://www.history.ucsb.edu/faculty/marcuse/classes/201/articles/08Connerton7TypesFor getting.pdf [dostęp: 28 XI 2017].

14 J. Staniszkis, op. cit., s. 190. 
[...] miasto się zbuntowało, bo nie chodziło tu o "trudności gospodarcze", a o byt, wolność i własną tożsamość. Przez kilkanaście godzin było wolne. Podjęło walkę, którą musiało przegrać. Rana pozostała na dziesiątki lat - miasto nie było już tak skore do buntu w kolejnych przełomowych latach PRL ${ }^{15}$.

W przypadku Europejskiego Centrum Solidarności tekst jest jeszcze bardzie wzniosły: wystawa stała dedykowana jest:

[...] historii Solidarności i ruchów opozycyjnych, które doprowadziły do przemian demokratycznych w całej Europie Środkowo-Wschodniej [...] Zmiany zainicjowane w Polsce pociągnęły za sobą przeobrażenia w całym bloku wschodnim. Po upadku systemu komunistycznego, kraje Europy Środkowo-Wschodniej weszły na drogę demokracji. W konsekwencji rozpadu Związku Radzieckiego powstały nowe, niepodległe państwa ${ }^{16}$.

Obie ekspozycje wyraźnie kierują się misją kreowania autopozytywnego wizerunku narodu, a jednocześnie prezentują naszą wyjątkowość światu. Wydarzenia i procesy, które reprezentują (historia Solidarności w przypadku ECS oraz pierwsze masowe wystąpienie przeciwko władzy komunistycznej w przypadku Muzeum Czerwca 1956) świetnie spełniają funkcję mitu założycielskiego stanowiącego fundament dla nowego, wolnego społeczeństwa.

W obu przypadkach mamy do czynienia ze spójną linią narracyjną: komunizm przedstawiony jest jako obca i wroga siła narzucona zniewolonemu społeczeństwu, które jednak doprowadzone do ostateczności i dysponujące moralną przewagą w ostateczności zwycięża (choć kosztem wielu ofiar). Koherencja opowieści wyraża się choćby przez nazwy sal w ECS: Narodziny Solidarności, Siła bezsilnych, Solidarność i nadzieja, Jan Paweł II, Wojna ze społeczeństwem, Droga do demokracji, Triumf wolności.

W tym wypadku ,zapomnieniu”, a raczej świadomemu „wymazaniu” podlega cały zestaw społecznych postaw, które Krystyna Kersten określiła jako „przystosowanie"17, Józef Tischner jako homo sovieticus ${ }^{18}$, a Leszek Kołakowski „poczuciem normalności”. Ten ostatni pisze:

$15 \mathrm{http} / / /$ www.muzeumniepodleglosci.poznan.pl/index.php?module=htmlpages\&fun c=display\&pid=5 [dostęp: 13 VIII 2015].

16 http://www.ecs.gda.pl/title,Wystawy,pid,20.html [dostęp: 15 VIII 2015].

17 K. Kersten, Między wyzwoleniem a zniewoleniem. Polska 1944-1956, Londyn 1993.

18 "Komunizm jawi się jako system nie narzucony i obcy, ale mający polskich zwolenników i wyznawców, zaistniał również homo sovieticus, czyli pewien typ człowieka, który wyjątkowo dobrze się czuł w tamtym ustroju (nikt go do tego nie zmuszał i nie był jego ideowym wyznawcą)". Zob. J. Tischner, Homo sovieticus. Między Wawelem a Jasna Góra, „Tygodnik Powszechny” 1990, 25, w: Spór o Polskę 1989-99. Wybór tekstów prasowych, red. P. Śpiewak, Warszawa 2000, s. 111. 
[...] ogromna większość żyła w poczuciu normalności chwilami tylko przerywanej: ludzie chodzili do szkół i na uniwersytety, wybijali się na rozmaite stanowiska w administracji, żenili się i rozwodzili, nie mając poczucia obcości w stosunku do kraju, gdzie żyli, kraju niesuwerennego, którego rządów nie wybierali i opartego na ideologii zgoła już śmiesznej, której nikt na serio nie brał. [...] Nie ma [...] sensu [...] wmawianie ludziom, że po prostu 45 lat mają wytarte z życiorysów, że jakby wcale nie żyli i wszystko w pustce przepadło ${ }^{19}$.

W przypadku podobnych reprezentacji nie eksponuje się faktów niepasujących do narracji tożsamościowej, np. faktu, że większość postulatów Solidarności to były postulaty socjalne, a nie polityczne (chociaż najważniejszy dla strajkujących był pierwszy, dotyczący powstania wolnych związków zawodowych), celem zaś był „socjalizm z ludzką twarzą", a nie liberalny kapitalizm. Wyraźna linia narracyjna i spójna opowieść nie dopuszcza wieloznaczności i sporów, które łatwo zauważyć, słuchając chociażby wypowiedzi bezpośrednich świadków tamtych wydarzeń.

Od strony formalnej obie ekspozycje można określić jako narracyjne rekonstrukcje przeszłości z pretensjami do neutralności i obiektywizmu. Oprócz tradycyjnych metod ekspozycyjnych, czyli artefaktów z epoki, ekspozycje prezentują najnowsze rozwiązania technologiczne. Zwiedzający mają dostęp do projekcji elektronicznych, gdzie zgromadzone są fotografie, filmowe materiały archiwalne, dokumenty, mapy, biogramy, kalendaria czy wycinki prasowe. Wystawy narracyjne charakteryzuje wyraźny realizm, zwany realizmem percepcyjnym, czyli takim, który przywołuje „namacalną rzeczywistość faktów w oparciu o widzialną prawdę, o moc percepcji wzrokowej" ${ }^{20}$. Przestrzegany jest wymóg naukowości ekspozycji, a więc jej logiczny układ oraz pogrupowanie i rozmieszczenie eksponatów w taki sposób, by tworzyły zwartą i przejrzystą całość, w której poszczególne prezentowane zjawiska pozostają w związkach przyczynowo-skutkowych i czasowo-przestrzennych oraz w której tematy drugoplanowe, podrzędne wypływają z zasadniczego tematu ekspozycji ${ }^{21}$.

Drugi, wyodrębniony przeze mnie typ wystaw, to ekspozycje ukazujące martyrologiczny i mesjański etos niepodległościowy w formie skrajnej, czyli męczeńskiej śmierci za wolność. Takie upamiętnienia odwołują się do tyrtejskiego nurtu polskiego romantyzmu, który za Tyrteuszem, greckim poetą z VII w. p.n.e., wzywał do nieustępliwej walki w obronie ojczyzny. Najsłynniejsze słowa Tyrteusza: „Rzecz to piękna zaprawdę, gdy

19 L. Kołakowski, PRL - wesoły nieboszczyk?, „Tygodnik Powszechny” 1995, 7, w: Spór o Polskę, s. 137.

20 L. Chouliaraki, W stronę analityki mediacji, w: Krytyczna analiza dyskursu. Interdyscyplinarne podejście do komunikacji społecznej, red. A. Duszak, N. Fairclough, Kraków 2008, s. 318.

21 P. Unger, Muzea w nauczaniu historii, Warszawa 1988, s. 18. 
krocząc w pierwszym szeregu / Ginie człowiek odważny, walcząc w obronie ojczyzny... / Walczmy mężnie w obronie naszej ziemi i dzieci, choć byśmy zginąć musieli..."22 oznaczały postawienie wolności ojczyzny na najwyższym miejscu w hierarchii wartości każdego patrioty ${ }^{23}$.

Do tego typu ekspozycji zaliczam izby pamięci, np. Izbę Pamięci Ofiar Terroru Komunistycznego w Warszawie oraz Izbę Pamięci Terroru Komunistycznego w Tomaszowie Lubelskim, a także Muzeum Sługi Bożego Księdza Jerzego Popiełuszki w kościele św. Stanisława Kostki w Warszawie. Charakterystyczne dla martyrologicznych upamiętnień jest wyraźne zaakcentowanie nazwisk ofiar (jeśli możliwe to ze zdjęciami) oraz ich katów. Ci pierwsi stanowią idealny symbol bojowników o wolność. Śmierć nadaje ostateczny i pełny sens moralny ich działalności. Kaci i mordercy $\mathrm{z}$ wielu powodów nie zostali ukarani $\mathrm{w}$ ogóle lub (co do tego panuje powszechny konsensus) zostali ukarani niewystarczająco, a zatem ich obecność w przestrzeni uświęconej jest swoistym uzupełnieniem nieodbytej czy też niepełnej kary: moralną sankcją i ostatecznym potępieniem.

Kolejny punkt wspólny martyrologicznych (czy "tyrtejskich") ekspozycji to wierne odzwierciedlenie przestrzeni, w której ofiary były katowane i/lub zamordowane. $W$ obu izbach pamięci zrekonstruowano pokoje przesłuchań i cele. W Muzeum Księdza Jerzego Popiełuszki znajdują się autentyczne Drzewa-Świadkowie jego męczeńskiej śmierci (wycięte z lasu, w którym J. Popiełuszko był katowany) oraz zrekonstruowany fragment tamy na Wiśle we Włocławku (miejsce odnalezienia zwłok). Obok na ścianie odwiedzający może zobaczyć drastyczne fotografie z sekcji zwłok księdza oraz części garderoby, w której go znaleziono.

Podobne ekspozycje najchętniej lokowane są w miejscach autentycznych, gwarantujących odczuwanie przez zwiedzających "aury”, stanowiącej pomost między teraźniejszością i przeszłością. Izba Pamięci Ofiar Terroru Komunistycznego w Warszawie mieści się w historycznej siedzibie Informacji Wojskowej (przy ul. Oczki) w miejscu, gdzie znajdował się Areszt Śledczy. Cele aresztantów oraz pokoje służące do ich przesłuchiwania zostały odtworzone. Izba pamięci w Tomaszowie Lubelskim znajduje się $\mathrm{w}$ dawnym budynku Powiatowego Urzędu Bezpieczeństwa (funkcjonował w latach 1944-1956). Tutaj również zrekonstruowano pokój przesłuchań, jednak z braku autentycznych obiektów posłużono się kopiami. Ciekawym przykładem dążenia do autentyzmu jest odnalezienie i przewiezienie na miejsce ekspozycji drzwi z aresztu milicyjnego (przy

${ }^{22}$ Wybór poezji antycznej, http://hamlet.edu.pl/data/uploads/teksty/wybor-poezjiantycznej.pdf [dostęp: 15 VIII 2015].

23 Zob. np. M. Janion, M. Żmigrodzka, Romantyzm i historia, Gdańsk 2001, s. 387-393. 
ul. Zamojskiej), które przypominają te oryginalne z Aresztu Śledczego. Autentyczne są kraty w oknach i nieliczne elementy w celach ${ }^{24}$. Obiekty należące do ofiar lub choćby kopie pisanych przez nie listów pełnią funkcję relikwii. Na wystawach można obejrzeć dokumentalne filmy i/lub relacje świadków.

Muzeum ks. Popiełuszki utworzono w kościele św. Stanisława Kostki na Żoliborzu, gdzie kapłan odprawiał słynne msze za Ojczyznę (fragmenty nagranych mszy można obejrzeć na monitorach na wystawie). Na terenie parafii znajduje się również grób księdza Popiełuszki, który jest miejscem pielgrzymek wiernych. Warto jednak dodać, że ks. J. Popiełuszko od momentu śmierci traktowany był jako bohater narodowy i chrześcijański męczennik, bohater polski i solidarnościowy, obrońca praw człowieka, orędownik wartości ogólnoludzkich. Do 1989 r. był przede wszystkim symbolem Solidarności, uosabiał moralną siłę ruchu. Dopiero po roku 1989 zaczął w kulcie księdza Popiełuszki przeważać motyw religijny ${ }^{25}$.

Patrząc z perspektywy formalnej, drugi typ ekspozycji kreuje doświadczenie afektywne, wykorzystując autentyczne przestrzenie i obiekty. Afekt (czyli najprościej rzecz ujmując ucieleśnione formy wiedzy, „myślenie ciałem") przez wywoływanie emocjonalnych reakcji wpływa na rozumienie przeszłości u publiczności, angażując ją emocjonalnie. Obiekty w funkcji relikwii wpływają na atmosferę wystaw, widz doświadcza zderzenia teraźniejszości z przeszłością i czuje, że wchodzi w inny świat. Taka afektywna odpowiedź jest jeszcze podkreślona nieobecnością i pustką w niegdyś wypełnionych cierpieniem miejscach.

Typ trzeci wystaw to reprezentacje, które określiłam jako nostalgiczne. Należą do nich: Muzeum PRL w Rudzie Śląskiej oraz Czar PRL w Warszawie.

Analiza podobnych ekspozycji wymaga przede wszystkim dookreślenia pojęcia nostalgii, która $\mathrm{w}$ tym wypadku nie oznacza chęci powrotu do przeszłości czy tęsknoty za komunizmem. Według Freda Davisa nostalgia (XVII-wieczny termin medyczny ukuty do opisu melancholii szwajcarskich najemników walczących za granicą) nie jest po prostu tęsknotą za przeszłościa, ale odpowiedzią na warunki teraźniejszości. Nostalgia jest odczuwana silniej w czasach niezadowolenia, niepokoju czy rozczarowania lub niepokojów społecznych. Pamięć nostalgiczna filtruje i odrzuca nieprzyjemne aspekty przeszłości (i naszego poprzedniego ,ja”), kreując

24 Za wszystkie informację dziękuję Panu Jarosławowi Antoszewskiemu, opiekunowi Izby Pamięci w Tomaszowie Lubelskim, z którym spotkałam się i rozmawiałam 13 lipca 2015 r.

25 E.K. Czaczkowska, T. Wiścicki, Ksiądz Jerzy Popiełuszko, Warszawa 2004, s. 358-359. 
wysokie poczucie własnej wartości, które pomaga przetrwać niepokoje, obawy i troski teraźniejszości. Zbiorowo, nostalgia dostarcza głębokiej więzi łączącej i identyfikującej pokolenie. Pomaga pokonać frustrację wynikającą z poczucia utraty cennych wartości ${ }^{26}$.

Nie ma zatem mowy o gloryfikacji PRL, ale wielu osobom, które pamiętają dawny ustrój, kojarzy się on z prostotą stosunków międzyludzkich, ciepłem, życzliwościa, regułami, które znali, do których byli przystosowa$\mathrm{ni}^{27}$. Ireneusz Krzemiński i Paweł Śpiewak piszą: „[...] można tu mówić o dość szeroko obecnym przekonaniu, że świat społeczny był wówczas może mniej kolorowy, mniej dynamiczny; że było mniej przebojowości, pazerności i miejsca dla ludzkich ambicji, ale za to panowało wówczas więcej ciepła w stosunkach międzyludzkich"28.

Filtr nostalgii zmienia przeszłość oraz zamienia trudy i absurdy życia w państwie komunistycznym na „oswojony” komunizm codzienny. W grę wchodzi tu również zjawisko, o którym pisze Andrzej Friszke: upływ czasu miał znaczący wpływ na samoświadomość polskiego społeczeństwa, które w coraz większym stopniu składało się z ludzi nieznających innej rzeczywistości niż peerelowska. Sprzyjało to internalizacji systemu, czyli przyjmowaniu go za własny ${ }^{29}$.

Muzeum PRL w Rudzie Śląskiej i Czar PRL w Warszawie to ekspozycje stanowiące rekonstrukcję przeszłości w ramach ograniczonej przestrzeni i mające wywołać u publiczności poczucie przebywania w czasie minionym, który nie jest nawet ściśle określony (poza ogólnym umocowaniem w czasach PRL). Obie rekonstruują najbardziej typowe dla codzienności przestrzenie życia: wnętrze mieszkań (przedpokój, kuchnia, pokój), sklep (z waga, kartkami na artykuły spożywcze, dawnymi banknotami), a także przynależące do strefy oficjalnej gabinety partyjnych urzędników. Pomieszczenia wypełnione są przedmiotami o niewiadomym pochodzeniu (obiekty często pochodzą ze zbiórki publicznej) i z różnych okresów PRL. Właściwie każdy odwiedzający (z pokolenia osób pamiętających poprzednią epokę) odnajdzie coś, co skojarzy mu się z dzieciństwem lub młodością. Obiekty wchodzą w rolę „pamiątek”, są zakorzenione w nostalgicznej tęsknocie za przeszłością, która z perspektywy czasu postrzegana jest jako lepsza i pełniejsza od trudnej teraźniejszości. Pamiątki nadają sens

26 F. Davis, Yearning for Yesterday: A Sociology of Nostalgia, London 1979, s. 105.

27 I. Krzemiński, P. Spiewak, Druga rewolucja w małym mieście. Zmiana ustrojowa w oczach mieszkańców Mławy i Szczecinka, Warszawa 2001, s. 67.

28 Ibidem, s. 68.

29 A. Friszke, Jakimpaństwem była PRL wlatach 1956-1976?, „PamięćiSprawiedliwość” 2006, 2, s. 22, http://ipn.gov.pl/_data/assets/pdf_file/0007/48688/1-18453.pdf [dostęp: 17 VIII 2015]. 
doświadczeniu, które staje się coraz bardziej odległe, budują mity kontaktu i obecności przeszłości w chwili obecnej ${ }^{30}$.

Zaletą rekonstrukcji jest niewątpliwie emocjonalne zaangażowanie widzów, trudniejsze do osiągnięcia w przypadku klasycznej, zobiektywizowanej narracji. Okres socjalizmu to nie tylko decyzje polityków, kryzysy, plany gospodarcze etc. To również codzienne życie ludzi, którzy - jak się okazuje - zachowali we wspomnieniach wiele jasnych stron epoki i z przyjemnością wracają myślami do "starych, dobrych czasów”. Totalitaryzm $\mathrm{w}$ tej wersji jest czasem odległym, bezpiecznym, a wręcz przyjaznym.

Formalnie obie wystawy to rekonstrukcje z cechami inscenizacji, wręcz dekoracji (Muzeum w Nowej Rudzie służy młodym parom jako swoiste atelier dla sesji ślubnych). Bazują na autentycznych przedmiotach z epoki, najchętniej najbardziej typowych, uzupełnianych fotografiami (Czar PRL). Artefakty stają się nośnikami wspomnień, wspomagają emocjonalne przeżycie, doświadczenie „podróży w czasie”.

Ćwierć wieku po upadku komunizmu społeczeństwa Europy Środkowo-Wschodniej są wciąż w stanie transformacji i mają większe niż ustabilizowane społeczeństwa zachodnie potrzeby w zakresie samoidentyfikacji i tworzenia opowieści integrujących i pomagających kreować nowa postkomunistyczną tożsamość. Muzea i ekspozycje historyczne, które są swoistym rezerwuarem sposobów reprezentacji zjawisk minionych oraz kluczowym elementem procesów racjonalizacji i instytucjonalizacji historii, pomagają $\mathrm{w}$ interpretacji trudnej przeszłości i współtworzą obowiązujący kanon pamięci o niedawnych wydarzeniach.

Polski kanon jest wciąż na etapie kształtowania i czasami burzliwych debat. Polska pamięć o przeszłości (niedalekiej) jest podzielona i niejednokrotnie pełna sprzeczności. Odnajduję w niej trzy główne nurty (tożsamościowy-heroiczny, martyrologiczny i nostalgiczny), chociaż modele przeze mnie wyodrębnione to swoiste typy idealne, a realne ekspozycje są często hybrydowe, tzn. łączą w sobie różne elementy, tworząc synkretyczną całość.

Zupełnie inaczej sytuacja wygląda w Europie Zachodniej, gdzie reprezentacji komunizmu właściwie nie ma, oprócz powstałego niedawno Domu Historii Europejskiej (House of European History - HEH) w Brukseli otwartego dla publiczności 6 maja 2017 r. Pomysłodawcą muzeum jest były przewodniczący Parlamentu Europejskiego Hans-Gert Pöttering,

${ }^{30}$ Więcej o obiektach-pamiątkach zob.: S. Pearce, Museum, Object and Collections: A Cultural Study, Washington D.C. 1992, s. 7 oraz eadem, Collecting Reconsidered, w: Museum Languages: Objects and Texts, red. G. Kavanagh, London-New York 1991, s. 139-140. 
który zainicjował projekt w 2007 r. Uważał on, że podobna placówka funkcjonująca w tym miejscu jest dodatkową szansą na tworzenie europejskiej świadomości:

Nie chcemy europejskiego centralizmu - twierdzi - chcemy natomiast, żeby nasza tożsamość narodowa nie stanowiła przeciwieństwa tożsamości europejskiej, gdyż są one nierozłączne. Jedność w różnorodności [...] Muzeum pokazuje też, dlaczego ostatecznie, pomimo wojen i konfliktów w Europie, możliwy był i jest pokój ${ }^{31}$.

Muzeum mieści się w Parku Leopolda, w budynku nazwanym na cześć amerykańskiego filantropa George’a Eastmana. Gmach, pierwotnie przeznaczony na potrzeby kliniki dentystycznej, został zaprojektowany przez szwajcarskiego architekta Michela Polaka, znanego z tworzenia w stylu art déco, a w szczególności słynącego z projektu brukselskiego Résidence Palace. Sam Park Leopolda wraz z obiektami zabytkowymi, takimi jak Instytut Pasteura czy Biblioteka Solvay od 1976 r. jest objęty ochroną.

Projekt muzeum był skierowany do turystów z UE i spoza Europy, którzy odwiedzając Brukselę i siedzibę Parlamentu Europejskiego, przy okazji mogą zwiedzić także Dom Historii Europejskiej. Placówka według planów miała stanowić nowoczesne centrum wystawowe, dokumentacyjne i informacyjne o powierzchni ok. 4 tys. mkw., mieszczące ekspozycję stałą dotyczącą historii Europy oraz wystawy czasowe ${ }^{32}$.

Projekt od samego początku był uważany za „trudny” i budził zastrzeżenia, m.in. polskich eurodeputowanych zwracających uwagę na „błędy i pominięcia historyczne" związane z rolą Polski w historii Europy ${ }^{33}$. Koncepcja nie podobała się również w Wielkiej Brytanii, gdzie próba ustalenia jednej wspólnej wersji wydarzeń historii 27 zróżnicowanych państw członkowskich została skrytykowana przez brytyjski ośrodek analityczny Civitas, według którego: „Dom Historii Europejskiej nie może osiągnąć niczego prócz nieszczerego paradoksu, próbując przedstawić historię wszystkich 27 państw, a w rzeczywistości nie odnosząc się do historii

31 B. Cöllen, Europa ma własne muzeum: Dom Historii Europejskiej, http://www. dw.com/pl/europa-ma-w\%C5\%82asne-muzeum-dom-historii-europejskiej/a-38737681 [dostęp: 15 VII 2017].

32 http://www.rp.pl/artykul/235189-Powstanie-Dom-Historii-Europejskiej-.html [dostęp: 15 VII 2017].

${ }_{33}$ Zgłoszone poprawki dotyczyły m.in. pominiętej zupełnie wojny bolszewickiej i bitwy pod Wiedniem, oporu Polski podczas II wojny światowej, związków między "Solidarnością" i działaniami papieża Jana Pawła II a upadkiem komunizmu Zob. I. Czerny, Dom Historii Europejskiej ma już budżet i ma ruszyć w 2014 roku, http://dzieje.pl/aktualnosci/ dom-historii-europejskiej-ma-juz-budzet-i-ma-ruszyc-w-2014-roku [dostęp: 15 VII 2017]. Na gotowej wystawie tych elementów jednak nie uwzględniono. 
w ogóle ${ }^{\prime 34}$. Krytyce poddane zostały nie tylko treści historyczne muzeum, ale również koszty jego utworzenia, szczególnie że muzeum powstawało w czasie kryzysu ekonomicznego i recesji. Marta Andreasen, posłanka do Parlamentu Europejskiego z partii nacjonalistycznej Wielkiej Brytanii, stwierdziła, iż "Jest to wbrew wierze i logice, że w epoce cięć budżetowych posłowie do Parlamentu dysponują ogromną sumą pieniędzy, która pozwoli na sfinansowanie tak rażąco narcystycznego projektu"35.

Wysuwane zastrzeżenia co do treści ekspozycji wynikały, jak się wydaje, głównie z niezrozumienia idei muzeum, które nie powstało po to, by zaprezentować zarys historii pojedynczych państw europejskich, czy też upamiętnić określone wydarzenia historyczne, ale by pokazać $\mathrm{w}$ tych historiach elementy wspólne i na tej podstawie zdefiniować tzw. europejską tożsamość. Innym problemem są odpowiedzi na pytania, czy taka misja w ogóle była możliwa do zrealizowania (w związku z istniejącymi fundamentalnymi różnicami zdań co do interpretacji pewnych faktów historycznych) oraz na ile tak założony cel został w Domu Historii Europejskiej osiągnięty.

Ekspozycja stała rozmieszczona jest na czterech piętrach budynku (plus wystawy czasowe na parterze), a od wejścia po najwyższe piętro towarzyszy jej instalacja artystyczna „Cyklon idei i słów” symbolizująca proces tworzenia się złożonej, trudnej i skomplikowanej, ale pojedynczej struktury - europejskiej tożsamości. Krzysztof Pomian pisał w 2007 r., kiedy muzeum nie miało jeszcze swojej siedziby i organizowane byłe jedynie wystawy czasowe:

[...] historia Europy nie jest tryumfalnym marszem ku jedności. Były okresy, gdy tendencje jednoczeniowe brały górę nad odśrodkowymi, i były takie, gdy wcześniejsza jedność ulegała rozpadowi, co wyrażało się w wojnach na skalę całego kontynentu, jeśli nie całego świata. Otóż, jeśli coś zdarzyło się w przeszłości, i to co najmniej dwukrotnie, to może zdarzyć się również w przyszłości. Dlatego też jesteśmy przekonani [...] że obecne stadium integracji europejskiej nie ma zapewnionego sukcesu ${ }^{36}$.

Obecna wystawa jest rozwinięciem i uzasadnieniem powyższej myśli.

Ekspozycja rozpoczyna się przypomnieniem greckiego mitu Europy, od którego wywodzi się nazwa kontynentu, ale realny początek europejskiej historii wyznacza na wiek XIX, kiedy Europa stała się dzięki rewolucji burżuazyjnej i przemysłowej światową potęgą. To właśnie w tamtym okresie pojawiły się podstawowe dla współczesności wartości: prawa

\footnotetext{
${ }^{34} \mathrm{http}: / /$ www.heltechnic.pl/info_Dom_Historii_Europejskiej [dostęp: 15 VII 2017].

35 Row Brewing as Cost of New Brassels History Museum Soars, http://www.dailymail. co.uk/travel/article-1373596/Brussels-House-Of-European-History-museum-Row-brewing-escalating-costs.html [dostęp: 15 VII 2017].

${ }^{36}$ K. Pomian, Muzeum Europy, "Muzealnictwo” 2007, 48, s. 225.
} 
człowieka, prawa obywatelskie, demokracja, nacjonalizm, a w ekonomii: industrializacja, wolny rynek oraz napędzające rozwój i kulturę masową wynalazki (fotografia, kino, telefon).

Wcześniejsze lata i epoki są ujęte w ogólnikowy zestaw haseł stanowiących podstawę do mówienia o wspólnej pamięci i kulturowym fundamencie europejskim: chrześcijaństwo, oświecenie, demokracja, kapitalizm, praworządność, humanizm, państwo narodowe, filozofia, rewolucje, marksim-komunuzm-socjalizm, ale także kolonializm, handel niewolnikami, ludobójstwo i terror państwowy. Każde $\mathrm{z}$ tych zagadnień symbolizowane jest przez jeden obiekt, np. figurkę papieża, kajdany czy grę planszową „Strajk!”, w którą grywała rodzina Marksa.

Rok 1914 i I wojna światowa to na wystawie punkt zwrotny w dziejach Europy, gdyż traumatyczny konflikt zbrojny, sam w sobie katastrofalny, stanowił początek kolejnego stulecia będącego tłem dla narodzin dwóch zbrodniczych systemów - stalinizmu i narodowego socjalizmu. Demokracja parlamentarna rozwijała się $\mathrm{w}$ praktyce jednocześnie $\mathrm{z}$ dyktaturami: komunistyczną i nazistowską. Oba totalitaryzmy są na ekspozycji zestawione, na wielkich monitorach pojawiają się fragmenty dokumentalnych filmów pokazujących marsze i parady z wielkimi portretami wodzów i symbolami obu reżimów. Różnice ideologiczne nie są zaakcentowane, ale już na tym etapie reprezentacji towarzyszy dysproporcja. Totalitaryzm nazistowski jawi się jako gorszy ze względu na konsekwencje, czyli Holokaust, któremu poświęcona jest nie tylko osobna gablota, ale nawet oddzielna minisalka nosząca nazwę „Pamięć o Holokauście”. Ofiarom komunizmu, gułagom, terrorowi stalinowskiemu, głodowi na Ukrainie nie poświęcono na wystawie aż takiej uwagi. To oczywisty znak czasów, gdyż dyskurs dotyczący Zagłady jest od przynajmniej 20 lat bardzo silny na Zachodzie i mocno wpływa na kształtowanie pamięci o wojnie i nazizmie. Jestem ostatnią osoba, która podważałaby wagę nazistowskiego ludobójstwa, jednak na ekspozycji poświęconej historii Europy powinna zostać zachowana równowaga, gdyż jej brak może być krzywdzący dla ofiar innych masowych zbrodni. Teza, że „Zagłada europejskich Żydów pod względem skali stopnia biurokratyzacji nie znajduje porównania z żadnym innym wydarzeniem $w$ historii" ${ }^{37}$ sama w sobie jest dla wielu badaczy (nie rewizjonistów) kontrowersyjna ${ }^{38}$, nie mówiąc o tym, że nie wspomina o innych ofiarach Holokaustu. Cenne za to wydaje się wskazanie

37 Dom Historii Europejskiej. Przewodnik kieszonkowy, Bruksela 2017, s. 10.

38 Ogólnoświatową dyskusję o wyjątkowości Zagłady i konsekwencjach przyjęcia takiej, a nie innej tezy przytoczyłam w pracy Holocaust. Problemy przedstawiania, Lublin 2005, s. 11-22. 
tych procesów, które doprowadziły do narodzin obu reżimów, np. kryzys ekonomiczny lat trzydziestych XX w., wyzysk, frustracja społeczna.

II wojna światowa (poprzedzona fragmentem wystawy dotyczącej wojny domowej w Hiszpanii) przedstawiona jest z perspektywy cierpień milionów zwykłych ludzi, a nie decyzji wodzów, strategii wojennych czy decydujących bitew. Wpisuje się to w szerszą tendencję widoczną w światowym muzealnictwie: koncentracji na ofiarach, która, co prawda, spycha na dalszy plan sprawców, ale akcentuje wyjątkowość i ekstremalność doświadczenia wojny poprzez straty poniesione przez ludność cywilną. Nie są to ofiary heroiczne (walczące w imię sprawy, odnoszące „moralne zwycięstwo"), ale martyrologiczne (ich śmierć nie może być wartościowana pozytywnie, nie daje się zracjonalizować w imię wartości wyższych, takich jak honor czy ojczyzna, jest przypadkowym i bezsensownym cierpieniem, utratą).

Najbardziej interesującą częścią ekspozycji w kontekście mojej pracy jest historia po 1945 r. Pierwszym zaskoczeniem jest wydzielony okres chronologiczny: 1945-1970, raczej niespotykany w pracach dotyczących Europy Środkowo-Wschodniej, drugim treść tego fragmentu wystawy podkreślona tytułem: "Zapewnienie zabezpieczenia społecznego". Od tego momentu w dziejach szczególnie trudno jest mówić o wspólnej historii Europy, stąd, jak się wydaje, decyzja twórców o zaakcentowaniu poprawy codziennych warunków bytowych ludności, które w latach pięćdziesiątych i sześćdziesiątych XX w. polepszają się w większym (Europa Zachodnia) lub mniejszym (Europa Wschodnia) stopniu. Jednak to, co od 1945 r. różni dwie części kontynentu, to dużo istotniejsze od socjalnych aspekty polityczne, prawnoustrojowe i kulturowe. Dyktatura komunistyczna wpłynęła w sposób decydujący na mentalność mieszkańców Europy Środkowo-Wschodniej, a wzrost gospodarczy i wprowadzenie państwa opiekuńczego podniosły jakość życia jedynie relatywnie (w stosunku do okresu wojny) i zupełnie nieznacznie (w stosunku do świata zachodniego). Wystawa prezentuje wschodnioeuropejski oraz zachodni design, wnętrza mieszkań, nowinki technologiczne i wskazuje, co praw$\mathrm{da}$, na różnice $\mathrm{w}$ standardzie, jednak nie poświęca uwagi kluczowym elementom systemu, takim jak represje, ograniczenie wolności, przymusowa kolektywizacja, zbrodnie i propaganda oraz wielu innym czynnikom charakterystycznym dla komunistycznego totalitaryzmu. Z ekspozycji wynika, że komunizm był gorszy głównie dlatego, iż nie zapewniał takich warunków ekonomicznych, jak wolnorynkowa gospodarka zachodnia.

W przypadku krajów Europy Środkowo-Wschodniej prędzej można spodziewać się milczenia czy wyparcia niż przedstawiania komunizmu z perspektywy ekonomicznej - chyba że w przypadku reprezentacji no- 
stalgicznych, odwołujących się do relatywnie krótkich okresów zwiększonej konsumpcji (jak lata siedemdziesiąte XX w. w PRL). Zasadniczo najważniejsze dla wystaw i muzeów są właśnie aspekty polityczne oraz bezwzględny ucisk reżimu na społeczeństwa i jednostki, natomiast warunki bytowe i życiowe schodzą na dalszy plan, występując ewentualnie jako tło wydarzeń lub temat wystaw czasowych.

Zrozumiałe jest, że ekspozycja pomija wiele elementów z historii narodowych poszczególnych państw, jednak reprezentacja komunizmu jako pewnego systemu, który wpłynął na obecną sytuację w Europie, musi budzić niedosyt. Podstawowym elementem ekspozycji we fragmencie obejmującym historię najnowszą stają się kolejne etapy zjednoczenia państw europejskich (od Europejskiej Wspólnoty Węgla i Stali po zakończenie zimnej wojny oraz przyjmowanie kolejnych państw z byłego bloku tzw. demokracji ludowych) i to jest motywem przewodnim wystawy. Ekspozycja akcentuje konieczność rezygnacji z partykularnych interesów i własnych uprawnień $\mathrm{w}$ imię ponadnarodowej solidarności i skuteczności. Patrząc z tej perspektywy, za jej główny temat uznałabym historię integracji europejskiej oraz zagrożenia wynikające z jej rozbicia, a nie historię Europy. Twórcy zostawiają również miejsce na własne refleksje i próbę odpowiedzi na pytania, czym jest europejskie dziedzictwo i co to znaczy być Europejczykiem. Idea ekspozycji jest szczytna i zrozumiała, jednak wymagała istotnych manipulacji materiałem historycznym w celu wykazania, że zjednoczenie (pomimo że trudne, o czym świadczą tomy dokumentów unijnych i traktatów eksponowanych na wystawie) jest jedyną szansą przetrwania tego, co w kulturze europejskiej najważniejsze.

Od samego początku ekspozycji towarzyszy kategoria pamięci, o jej znaczeniu przekonuje lektor wprowadzający na wystawę każdego odwiedzającego. Oprócz wyraźnie zaakcentowanej pamięci o Holokauście, pojawia się również informacja o wspomnieniach osób represjonowanych w epoce komunizmu, jednak zasadniczo odnoszę wrażenie, że pytanie o wspólną i podzieloną europejską pamięć pozostaje jedynie deklaratywne. Wystawa jako całość do kategorii pamięci nie nawiązuje, jest raczej skoncentrowana na upowszechnianiu europejskiej świadomości obywatelskiej i znaczeniu aktu wzniesienia się ponad państwowe i narodowe interesy. Pamięć o wojnach i kataklizmach jest jedynie instrumentem, który ma za zadanie ostrzegać przed skutkami zwycięstwa partykularyzmów.

Ekspozycja jest interesująca (choć nierówna) pod względem formalnym. Każdy z odwiedzających przy wejściu dostaje tablet, z którego może swobodnie i zgodnie z własnymi zainteresowaniami słuchać nagranych komentarzy oraz opisów do poszczególnych fragmentów wystawy. Dzięki temu rozwiązaniu na ekspozycji nie ma żadnych opisów czy tekstów. 
Co istotne, objaśnienia są dostępne we wszystkich językach unijnych. Tablety oprócz swoich zalet (indywidualne zwiedzanie zgodne z osobistymi preferencjami) mają jednak wadę: każdy z widzów zatopiony jest we własnej opowieści, nie ma możliwości dzielenia się doświadczeniem i emocjami oraz nawiązywania więzi społecznych, a te dwa aspekty są niezwykle istotne dla tożsamości muzeum jako instytucji kulturotwórczej.

Najdawniejsza historia Europy (od mitu Europy do rewolucji XIX w.) jest maksymalnie symboliczna i ograniczona do kilkunastu wręcz obiektów, równie dobrze zaprojektowana jest część poświęcona rewolucjom. Wybrane artefakty wydają się wręcz esencją historii Europy w tamtym okresie, prawdopodobnie dlatego, że takie przedmioty, jak kajdany, maszyna parowa, wynalazki funkcjonują w kulturze masowej jako łatwo rozpoznawalne ikony. Dużo słabiej na wystawie wypada wiek XX. Obiektów jest dużo więcej, ale niewiele $\mathrm{z}$ nich (maski gazowe symbolizujące bitwę pod Ypres, więźniarskie pasiaki, które występują we wszystkich reprezentacjach Zagłady) ma status ikoniczny.

Ekspozycja nie podąża za współczesnym trendem narratywizacji i teatralizacji przestrzeni muzealnej, ale nie stroni od nowoczesnych rozwiązań (duże nasycenie mediami). Jest rozwiązaniem hybrydowym: z jednej strony wraca do obiektu jako jądra ekspozycji muzealnej, z drugiej wprowadza nowe technologie.

Reasumując, wystawę określiłabym jako dydaktyczną ekspozycję „z tezą", która brzmi: tylko jedność (pomimo różnic) może uchronić Europę przed kataklizmami wojen i totalitaryzmów. W imię tej jedności należy wypracować w społeczeństwach obywatelską świadomość i poczucie wspólnoty, a można to uczynić jedynie poprzez koncepcję europejskiej tożsamości. Jeśli nawet istnienie tej ostatniej budzi wątpliwości ze względu na odmienne tradycje, historie narodowe, animozje pomiędzy narodami, to nic nie stoi na przeszkodzie, by ją stworzyć, akcentując to, co Europę łączy. Zasadniczo każda tożsamość jest społeczno-kulturowym konstruktem, a ekspozycja ma za zadanie stworzenie pewnego repozytorium wspólnie dzielonych doświadczeń, pojęć i idei, czyli europejskiego dziedzictwa.

\section{BIBLIOGRAFIA (REFERENCES)}

Assman A., From "Canon and Archive", w: The Collective Memory Reader, red. J.K. Olick, V. Vinitzky-Seroussi, D. Levy, Oxford 2011.

Assmann A., Między historia a pamięcią. Antologia, red. M. Saryusz-Wolska, Warszawa 2013. Chouliaraki L., W strone analityki mediacji w: Krytyczna analiza dyskursu. Interdyscyplinarne podejście do komunikacji społecznej, red. A. Duszak, N. Fairclough, Kraków 2008. 
Connerton P., Seven Types of Forgetting, „Memory Studies” 2008, 1, http://www.history. ucsb.edu/faculty/marcuse/classes/201/articles/08Connerton7TypesForgetting.pdf [dostęp: 28 XI 2017].

Czaczkowska E.K., Wiścicki T., Ksiądz Jerzy Popiełuszko, Warszawa 2004.

Davis F., Yearning for Yesterday: A Sociology of Nostalgia, London 1979.

Dom Historii Europejskiej. Przewodnik kieszonkowy, Bruksela 2017.

Friszke A., Jakim państwem była PRL w latach 1956-1976?, „Pamięć i Sprawiedliwość" 2006, 2, http://ipn.gov.pl/_data/assets/pdf_file/0007/48688/1-18453.pdf [dostęp: 17 VIII 2015].

Janion M., Żmigrodzka M., Romantyzm i historia, Gdańsk 2001.

Kersten K., Między wyzwoleniem a zniewoleniem. Polska 1944-1956, Londyn 1993.

Kołakowski L., PRL - wesoły nieboszczyk?, „Tygodnik Powszechny” 1995, 7.

Krzemiński I., Śpiewak P., Druga rewolucja w matym mieście. Zmiana ustrojowa w oczach mieszkańców Mławy i Szczecinka, Warszawa 2001.

Pomian K., Muzeum Europy, „Muzealnictwo” 2007, 48.

Pearce S., Collecting Reconsidered, w: Museum Languages: Objects and Texts, red. G. Kavanagh, London-New York 1991.

Pearce S., Museum, Object and Collections: A Cultural Study, Washington D.C. 1992.

Staniszkis J., Antropologia władzy. Między Traktatem Lizbońskim a kryzysem, Warszawa 2009.

Szpociński A., Przemiany obrazu przeszłości Polski: analiza słuchowisk historycznych dla szkót podstawowych 1951-1984, Warszawa 1989.

Szpociński A., II wojna światowa w komunikacji społecznej, w: Między codziennościa a wielka historia. Druga wojna światowa w pamięci zbiorowej społeczeństwa polskiego, red. P.T. Kwiatkowski, L.M. Nijakowski, B. Szacka, A. Szpociński, Gdańsk-Warszawa 2010.

Tischner J., Homo sovieticus. Między Wawelem a Jasna Góra, „Tygodnik Powszechny” 1990, 25 w: Spór o Polskę 1989-99. Wybór tekstów prasowych, red. P. Śpiewak, Warszawa 2000.

Unger P., Muzea w nauczaniu historii, Warszawa 1988.

Ziębińska-Witek A., Holocaust. Problemy przedstawiania, Lublin 2005.

Ziębińska-Witek A., Muzealizacja komunizmu w Polsce i Europie Środkowo-Wschodniej, Lublin 2018.

\section{Źródła internetowe}

Cöllen B., Europa ma własne muzeum: Dom Historii Europejskiej, http://www.dw.com/pl/ europa-ma-w\%C5\%82asne-muzeum-dom-historii-europejskiej/a-38737681 [dostęp: 15 VII 2017].

Czerny I., Dom Historii Europejskiej ma już budżet i ma ruszyć w 2014 roku, http://dzieje. pl/aktualnosci/dom-historii-europejskiej-ma-juz-budzet-i-ma-ruszyc-w-2014-roku [dostęp: 15 VII 2017].

http://ipn.gov.pl/_data/assets/pdf_file/0007/48688/1-18453.pdf [dostęp: 17 VIII 2014].

http://www.ecs.gda.pl/title,Wystawy,pid,20.html [dostęp: 15 VIII 2015].

http://www.heltechnic.pl/info_Dom_Historii_Europejskiej [dostęp: 15 VII 2017].

http://www.muzeumniepodleglosci.poznan.pl/index.php? $m o d u l e=h t m l p a g e s \& f u n c=d i-$ splay\&pid=5 [dostęp: 13 VIII 2015].

http://www.rp.pl/artykul/235189-Powstanie-Dom-Historii-Europejskiej-.html [dostęp: 15 VII 2017].

Row Brewing as Cost of New Brussels History Museum Soars, http://www.dailymail.co.uk /travel/article-1373596/Brussels-House-Of-European-History-museum-Rowbrewing-escalating-costs.html [dostęp: 15 VII 2017].

Wybór poezji antycznej, http://hamlet.edu.pl/data/uploads/teksty/wybor-poezji-antycznej. pdf [dostęp: 15 VIII 2015]. 


\section{ABSTRACT}

The aim of the article is to critically analyze and deconstruct museum narratives about communism in Poland and Western Europe a quarter century after the transformation. The research material is museum exhibitions interpreted in accordance with the methodology of visual research (composition analysis, content analysis, analysis of material objects, and analysis of meanings). On this basis, the author distinguishes three basic models of creating museum exhibitions about communism and compares them with the permanent exhibition in the House of European History in Brussels. The purpose of the studied exhibitions is mainly to shape the collective memory of audiences by creating a canon of knowledge about the recent past. The article is part of a broader project of studying exhibitions about communism in Central-Eastern Europe.

Key words: historical museums, communism, collective memory, museum narratives, institutionalization of history

\section{NOTA O AUTORZE}

Anna Ziębińska-Witek - doktor habilitowany, profesor UMCS, pracuje w Instytucie Kulturoznawstwa Uniwersytetu Marii Curie-Skłodowskiej w Lublinie. Historyk-metodolog, zajmuje się muzeologia, teoretycznymi problemami wiedzy o przeszłości oraz problematyką reprezentacji historii w werbalnych i wizualnych dyskursach kultury współczesnej. Autorka wielu publikacji, w tym dwóch książek: Holocaust. Problemy przedstawiania (Lublin 2005) i Historia w muzeach. Studium ekspozycji Holokaustu (Lublin 2011) oraz przekładu studium Berela Langa Nazistowskie ludobójstwo. Akt i idea (Lublin 2006). Stypendystka Fundacji Kościuszkowskiej (United States Holocaust Memorial Museum, Washington DC) oraz Fundacji Fulbrighta (Princeton University). E-mail: aziebin@poczta.onet.pl 